\title{
Primary Literacy Program: Integrating Reading and Writing in The Classroom
}

\author{
I. A. M. Dewi, N. N. Padmadewi, L. P. Artini \\ Universitas Pendidikan Ganesha \\ Singaraja, Bali, Indonesia \\ Nym.padmadewi@undiksha.ac.id
}

\begin{abstract}
This study aims at describing literacy program which integrates reading and writing in English for young learner classes in North Bali Bilingual Schools. The study follows a descriptive qualitative design, involving 4 teachers, school principal and 56 students of grade 4,5 , and 6 . The data are collected through classroom observation and interview with the teachers, students, and the school principal. The findings of this study show that there are several strategies that can be effectively implemented in the primary literacy program for young learners learning English as a foreign language. These strategies comprise cooperative literacy program, interactive storytelling, reading respond journal and novel study. Each of these strategies is described and the impacts of their implementation on young learners' ability to read and write in English are explained.
\end{abstract}

\section{Keywords - Literacy Program, Reading, Writing}

\section{INTRODUCTION}

Literacy skill is highly needed nowadays, and has recently become a major concern in Indonesian educational institutions. Padmadewi, Agustini, and Ari-ati (2013) explained that English literacy does not only expect the learners to be able to read and write, but also to be able to communicate fluently, independently and effectively in the society. The national phenomenon shows that the literacy skill of Indonesian children is very low compared to other countries. While Morrow et al (2003) agree that learning to read and write is the most complex task that humans should face. That is why the new policy in Education advocates that literacy program should be introduced from the primary school level. Literacy can be defined as the ability to read and write that relates to real-world literacy activities (Purcel-Gates et al, 2012; Haryanti, 2014).

The intensification of literacy program in Indonesia nowadays is marked by the launching of GLS (Gerakan Literasi Sekolah) or School Literacy Movement, that is, the implementation of literacy program in every school which is supervised by the Ministry of Education and Culture. This indicates that the government is very serious in helping young learners to build their literacy skills. However, there has been very little supervision and facilitation on how to improve literacy skill in English as a foreign language. As a matter of fact, to increase the literacy skill in a foreign language would be more challenging because English is not a language which is used to communicate in Indonesia.
Artini (2017) mentioned several reasons why it is considered important to start introducing English as a foreign language in primary schools. First, from the age perspective, the young learners are considered having more flexible 'tool' for learning a language (Long, 1990; Ara, 2009; Damar, et al., 2013). Second, the demands of English in the society result in positive attitudes towards learning the foreign language (Lamb, 2003; Artini, 2006; 2009b).

Therefore, the researcher conducted this study in one of the schools that have been proven successful in improving the English literacy skill of primary students. The purpose of this study is to describe literacy program which integrates reading and writing activities that gradually improves the primary school students' literacy skills in English as well as their reading habit.

Literacy is the foundation which is very important in children's lives. Even the literacy widely means the ability to read, write, speak, as well listen, the focus in this study is on the ability to read.

Kennedy, et al (2012) views the concept of emergent literacy is particularly significant. It is supported by Aistear (NCCA, 2009, p. 54) who views emergent literacy as developing through "play and hands-on experience where children see and interact with print as they build an awareness of its functions and conventions'. It could be concluded that it is important to take into account of the interconnectedness of oral language and reading and writing within the emergent literacy phase.

Reading is really important for the students. It is supported by Cambria and Guthrie (2010) which stated that reading is a tool to take students to the knowledge they wanted to achieve.

In addition, Bharuthram (2012) stated that reading is one of the most important academic tasks encountered by students. In 2004, the South African Department of Education (DoE) recognized reading literacy as one of the most important priorities in education. It is noted that that reading is taught most effectively with writing, as a means of integrated processes. Reading and writing are two complementary processes which are essential for academic success. Integrating reading and writing skills in EFL learning improves and enhances all basic skills and sub-skills in common. Most students forget about the importance of writing, because it allows better understanding and 
assimilation of knowledge. It is worth to note that integrating skills contributes to the mastery of foreign language during the whole study, it also develops an ability to express ideas freely (Pysarchyk \& Yamshynska, 2015).

English literacy in Indonesia in general, or in Bali in particular is more emphasized on "school-only literacy" activities. Structuralize phenomenon in this study is confirmed by the use of quantitative assessment which emphasizes more on the score rather than on the quality of student's performance. Assessment has the power to change people's lives (Shohamy, 2001 in McKay, 2006). Over the years, the type of assessment used more objective tests that provide less favorable backwash effects, and less use of authentic assessment. The use of assessment which quantitative oriented leads the society that sees more competence than the score obtained by the students instead of students' skills in literacy in the real world in the society. This phenomenon leads to incapacity students to use the language of authentic real world in literacy in the community (Padmadewi, 2015).

Primary literacy program is preparing learners to read and write by exposing them to skills building activities that promote good literacy habits. It is a very effective program in arousing students' interest and confidence in reading.

\section{METHOD}

This study is in the form of Qualitative re-search. Qualitative research is described as an un-folding model that occurs in a natural setting that enables researcher to develop a level of detail from high involvement in the actual experiences (Creswell, 1994 as cited in Williams, 2007)

The population of this study was the third, fourth, and fifth grade students of NBBS (North Bali Bilingual School). The total number of students in the population is 56 students.

The reason of choosing the fourth, fifth, and sixth grade students is because the students in these grade are already known how to read and write, and the reason of choosing NBBS as the subject is because North Bali Bilingual School is the only international school in Singaraja, Bali which have been proved to have a good innovative strategies to improve children's English literacy.

There were two types of instrument used in this study. The researcher used observation and interview to gain data.

The interview was conducted in the beginning of the study before the researcher conducting classroom observation. It is done because the researcher will not able to see or even understand the strategy used in the classroom, unless the researcher had interview about the strategy first with those who understand the strategy. That is why the researcher interviewed the school principal and the teacher.

According to Schostak, (2006: 54) as cited in Alshenqeeti (2014) interview is an extendable conversation between partners that aims at having 'in-depth information' about a certain topic or subject, and through which a phenomenon could be interpreted in terms of the meanings interviewees bring to it.
The observation in this study was conducted five times. The researcher was observing each strategy implemented in NBBS. Lasagabaster \& Sierra (2011) agreed that classroom observation can be a valuable tool in giving researchers a more comprehensive picture of what actually happens in class.

The qualitative data of this study were analyzed by using triangulation data. It was done through the classroom observation; interview with the headmaster, teacher, and the students in order to know the used strategy, the material, the activity, and how the students feel about the use of that strategy and material.

\section{RESUlt AND DiscuSSION}

There were some strategies found in the classroom observation. There were reading bodies, cooperative literacy program, interactive storytelling, reading respond journal, and novel study.

The choice of strategy used in the literacy program activity is motivated by the goals that have been determined by the school. One of the goals is to encourage students to work collaboratively. For this, the strategy used is 'Reading Body'. Students are paired and a reading material is prepared by the teacher. In the activity, one student is assigned to read and the other student should listen and draw an illustration. The result of this activity is usually a poster that will be displayed later. This activity is usually done by students in different grades. However, because schools are generally not possible for mixing student's grade, so it could be done in the same grade with different levels of ability.

This activity has been observed to have a motivating effect. Both students wanted to do their best. The reader had to do his/her job well so that his/her partner could do the illustration appropriately according to the text he/she listened to.

The second strategy used in literacy program named cooperative literacy program. Cooperative activity is known as a good activity for primary student. It is supported by Gillies \& Ashman (2003) which stated that co-operative learning is important in early childhood education. This kind of activity allows students to interact, collaborate, and build the skill of teamwork. When young children first come to a structured educational setting, their fledgling social and emotional skills and understandings are challenged in new and more complex ways. They will need to interact and negotiate with a large number of unfamiliar peers with different levels of social and emotional competencies, interests, cognitive abilities and interaction styles.

This cooperative literacy program implemented in NBBS is reading activity involving students with different grades, then the students choose a story book with their classmates and it will be presented later. Students are usually made it in drama performance. All students in that class should participate in all activities, such as in making property and so on. Later on, the door in their classroom will be decorated based on the theme of the story book they will present. This kind of activity is also a good way to train student's creativity. 
Besides, real-world literacy can be introduced by providing students with real world activities (Purcel-Gates, et. al, 2012)

The third one is interactive story telling. Hoguet (2014) defined interactive storytelling as the art of telling stories enhanced with technological, social or collaborative interactive features to offer content adapted to new behaviors in a rapidly changing cultural ecosystem. British council (2003) stated that stories create magic and a sense of wonder at the world. Storytelling is a unique way for students to develop an understanding, respect and appreciation for other cultures, and can promote a positive attitude to people from different lands, races and religions.

In NBBS, the interactive story telling allowed the teacher and the students to have a question and answer activity in order to keep students engaged. Storytelling is good for children's cognitive development and interactive storytelling can help foster this. It is supported by Speaker (2000) as cited in Wallin (2015) which states that practicing storytelling may increase students' language development. Moreover, students who have access to storytelling in terms of being told a story or telling a story, show an increased ability to listen actively for longer periods during the school day.

Reading response journal is an activity where reader has to reflect on what they think, share with a partner, revise what they think and whole group share (Alessi, 2010). In NBBS, it is an activity where students are allowed to read any novel which they like, and they have to make a summary of the novel with their own language in each chapter they had read. Later on, the teacher will give a response about their summary, and they can continue reading the novel. In this activity, students are trained to be responsible with their own learning. Teacher and student will have some discussions about the novels through journal. This is a good activity to make students build a habit to love reading. Response journals can be implemented at any levels/ grades.

The last strategy found in NBBS was novel study. Novel study is an activity where all students get the same novel to read. The students will be given tasks related to the novel, but the tasks of one student and the other will be different because the ability of each student is different. This activity will give a good impact on students' motivation. Each student will be motivated to do the task given by the teacher because those tasks will be quite challenging for them since every students got a task based on their ability.

\section{CONCLUSION}

Nowadays students read not because of their desire to read, but for the sake of completing the task. Foster students' interest in reading should be trained from an early age. In terms of reading books in English, where in Indonesia starting at the primary school level, teachers must be keen in finding strategies that can be used to foster students' interest in reading. As it is known to teach a language which is not used as a language to communicate in its environment will be more difficult.

The teacher has to be smart in determining strategies to improve students reading interest. By integrating the reading and writing skills, the students will certainly be easier to understand the lesson. It is supported by Cobine (1995) as cited in Giesen (2001) who stated that integration allows for multiple approaches to tasks, covering all learning styles. Students become better readers, writers and thinkers when they learn reading and writing together (Carson, 1993, Spack, 1998 in Giesen, 2001).

Besides, Giesen (2001) mentioned that writing activities motivate students to read and re-read in that they provide a purpose for reading and require students to become actively engaged with a text. Writing enhances students' understanding and improves the retention of what they read.

Integrating skills in EFL learning surely improves all basic skills. Integrating skills will also contribute to the mastery of foreign language.

Hence it becomes very reasonable to introduce integrated reading and writing activities for children, because the earlier they love to read, the sooner of the learning habits will become easily emerged. The higher the ability and fund of reading activities, the higher the fun and excitement of the children will appear. In a consequence they will more easily understand every lesson in school.

\section{References}

[1] Allesi, K. 2010. Reading response journal. Retrieved from http://orgsites.com/ar/nwarc/readingresponejournals.pdf [accessed 25 July 2017]

[2] Alshenqeeti, H. 2014. Interviewing as a Data Collection Meth-od: A Critical Review. English Linguistics Research, 3(1).

[3] Ariati, N. P. B., Padmadewi, N. N., \& Agustini, D. A. E. 2013. The implementation of innovative phonic approach for teaching english literacy for second graders of NBBS. e-Journal Program Pascasarjana Universitas Pendidikan Ganesha Program Studi Pendidikan Bahasa Inggris, $\quad$ Retrieved from https://ejournal.undiksha.ac.id/index.php/JPBI/article/view/4874 [accessed 27 July 2017]

[4] Artini, L. P. 2017. Rich Language Learning Environment and Young Learners' Literacy Skills in English. Binus University Journal. Vol.11 No.1 Retrieved from http://journal.binus.ac.id/index.php/Lingua/article/view/1587

[5] TeachingEnglish | British Council | BBC. (2017). Storytelling - benefits and tips. [online] Available at: http://www.teachingenglish.org.uk/article/storytelling-benefits-tips [Accessed 27 Jul. 2017].

[6] Cambria, J., and Guthrie, J. T. 2010. Motivating and engaging students in reading. Retrieved from http://www.literacyconnects.org/img/2013/03/Motivating-and-engagingstudents-in-reading-Cambria-Guthrie.pdf.

[7] Gillies, R. M., \& Ashman, A. F. 2003. Co-operative Learning: The social and intellectual outcomes of learning in groups. London: RoutledgeFalmer Teaching English 2003. Storytelling - benefits and tips. $\quad$ Rertieved from https://www.teachingenglish.org.uk/article/storytelling-benefits-tips

[8] Haryanti, T. 2014. Jambore Taman Bacaan Masayarakat http://www.triniharyanti.id/2014/02/membangun-budaya-literasidengan.html

[9] Purcell-Gates, V., et al. 2012. Measuring situated literacy ac-tivity: challenges and promises. Journal of Literacy Re-search 44(4) pp.396425 Retrieved from http://www.sagepub.com/journalsPermissions.nav. [ac-cessed 22 July 2017] DOI: 10.1177/1086296X12457167. 
[10] Kennedy, E., et al. 2012. Literacy in Early Childhood and Primary Education (3-8 years). ISSN 1649-3362. Re-trieved from http://www.ncca.ie/en/Publications/Reports/Literacy_in_Early_Childhoo d_and_Primary_Education_3-8_years.pdf

[11] Lasagabaster, D. and Sierra, J. 2011. Classroom observation: desirable conditions established by teach-ers. European Journal of Teacher Education, 34(4), pp.449-463.

[12] McKay, P. 2006. Assessing Young Language Learners. Cam-bridge: Cambridge University Press.

[13] Padmadewi, N.N. 2016. Techniques of promoting learning au-tonomy in the classroom. Journal of Education and Social Science. 3: pp.45-52

[14] Pysarchyk, O. L., \& Yamshynska N. V. (2015). The im-portance of integrating reading and writing for the EFL teaching. Kyiv, National
Technical University of Ukraine. Retrieved from http://ae.fl.kpi.ua/article/view/44298/40482

[15] Strickland, D. ed., (2003). Best Practices in Literacy Instruc-tion. 2nd ed. New York: The Guilford Press.

[16] Wallin, J. 2015. Storytelling and language development. re-trieved from https://dspace.mah.se/bitstream/handle/2043/18896/EX\%20FINAL.pdf? sequence $=2$

[17] Morrow C, Naumburg E, Dysmenorrhea, Morrow \& Naumburg, 2009 